\title{
Rehydration of high-protein-containing dairy powder: Slow- and fast-dissolving components and storage effects
}

\author{
Arnaud Mimouni $^{1 *}$, Hilton C. Deeth ${ }^{1}$, Andrew K. Whittaker ${ }^{2}$, \\ Michael J. GidLey ${ }^{3}$, Bhesh R. Bhandari ${ }^{1}$ \\ ${ }^{1}$ School of Land, Crop and Food Sciences, The University of Queensland, Hartley Teakle Building, \\ St. Lucia, QLD 4072, Australia \\ ${ }^{2}$ Centre for Magnetic Resonance, and Australian Institute of Bioengineering and Nanotechnology \\ (AIBN), The University of Queensland, St. Lucia, QLD 4072, Australia \\ ${ }^{3}$ Centre for Nutrition and Food Sciences, The University of Queensland, St. Lucia, QLD 4072, Australia
}

Received 30 March 2009 - Revised 27 November 2009 - Accepted 4 January 2010

Published online 9 February 2010

\begin{abstract}
As dissolution of powdered milk proteins is necessary for the expression of their functional properties, it is regarded as a critical property by the dairy industry. However, milk proteins exhibit a progressive loss of solubility during storage in the dry form, especially in the case of high-protein-containing powders such as milk protein concentrate (MPC). To further understand the mechanisms responsible for this loss of solubility, the rehydration process of MPC powder before and after storage at $23 \%$ equilibrium relative humidity and $24{ }^{\circ} \mathrm{C}$ for up to two months was studied. This work clearly showed that the storage-induced loss of milk protein powder solubility was due to changed rehydration kinetics and not to the formation of insoluble material in the course of storage. The concentrations of the various constituents of MPC (caseins, whey proteins, lactose, calcium, magnesium, phosphorus, sodium and potassium) were determined in the dispersed phase during the powder dissolution process. The results suggest that the release of micelles from powder particles is the rate-limiting step of the MPC rehydration process and is inhibited upon storage. In contrast, water penetration into the powder particles is shown not to be a rate-limiting factor as molecules larger than water (whey proteins and lactose) were freely released out of the powder structure in both fresh and aged MPCs.
\end{abstract}

rehydration / dairy powder / milk protein / casein micelle / solubility

\begin{abstract}
摘要 - 慢速和快速溶解化合物以及贮藏对高蛋白乳粉水合能力的影响。在乳品工业中, 溶 解性是乳粉最重要的特性之一。然而在干粉的穴藏期间, 乳粉的溶解性逐渐降低, 尤其是高 蛋白含量的乳粉, 如乳清浓缩蛋白。为了掌握和了解这种溶解性降低的机制, 研究了茂藏前 和在 $24{ }^{\circ} \mathrm{C}$ 、相对平衡湿度为 $23 \%$ 的条件下败藏 2 个月的乳清浓缩蛋白的水合过程。研究 结果证明了咜藏导致的乳清浓缩蛋白溶解能力降低原因是由于水化动力学机制发生了改变, 并 不是由于陉藏过程中形成了不溶性的化合物。在乳粉的溶解过程中，测定了分散相中不同乳 清浓缩蛋白组分的浓度 (酪蛋白、乳清蛋白、乳糖、钲、镁、磷、钠、钾)。酪蛋白胶束 从乳粉中释放速度是乳清浓缩蛋白水合作用的限制性因素，而穴藏抑制了这种释放过程。 相反, 无论是新鲜的还是败藏后的乳清浓缩蛋白, 水分子渗透到乳粉颗粒中的速度不是限 制因素, 因为, 那些比水分子大的分子 (乳清蛋白、乳糖) 都是游离于乳粉结构的外部。
\end{abstract}

\section{水合作用 / 乳粉 / 乳蛋白 / 酪蛋白胶束 / 溶解性}

*Corresponding author (通讯作者): arnaud.mimouni@hotmail.com 
Résumé - Réhydratation d'une poudre laitière à haute teneur en protéines : effets du stockage et des composants à dissolution rapide ou lente. La capacité d'une poudre de protéines laitières à se solubiliser est déterminante pour l'expression des propriétés fonctionnelles des protéines, elle est donc cruciale du point de vue industriel. Pourtant, les protéines de lait subissent une perte progressive de solubilité au cours du stockage sous forme déshydratée, particulièrement dans le cas de poudres à haute teneur en protéines telles que les concentrés de protéines de lait (CPL). Pour mieux comprendre les mécanismes à l'origine de la perte de solubilité de ces poudres, leur processus de réhydratation a été étudié avant puis après un stockage de deux mois à $24{ }^{\circ} \mathrm{C}$ sous une humidité relative de $23 \%$. Ce travail a clairement montré que la perte de solubilité induite lors du stockage était due à un ralentissement de la réhydratation et non à la formation de matériel insoluble. Les concentrations des différents constituants des CPL (caséines, protéines sériques, lactose, calcium, magnésium, phosphore, sodium, potassium) ont été mesurées dans la phase dispersée au cours de la réhydratation des poudres. Les résultats suggèrent que l'étape cinétiquement déterminante de la réhydratation des poudres de CPL est la libération des micelles de caséines dans la phase liquide. En revanche, la pénétration de l'eau dans les grains de poudres n'est pas un facteur limitant. En effet, des molécules plus volumineuses que l'eau (protéines sériques, lactose) diffusaient librement hors de la structure des grains de poudre, avant ou après stockage.

\section{réhydratation / poudre laitière / protéine laitière / micelle de caséine / solubilité}

\section{INTRODUCTION}

The production of high-protein-containing dairy powders is growing worldwide. Most of these powders are produced from pasteurized skim milk by ultrafiltration and diafiltration to retain casein micelles and whey proteins while allowing most water, lactose and soluble salts to pass through the membranes. Further removal of water takes place during vacuum evaporation and spray-drying steps to produce milk protein concentrate (MPC) powder [7, 20]. These powders are manufactured with various protein over dry matter ratios (w/w), such as $85 \%$ (MPC85) and $56 \%$ (MPC56), and used as ingredients by the food industry to improve gelling, foaming or emulsifying properties of the products as well as their nutritional value. For most applications, MPC has to be dissolved back into water, preferably at temperature between 15 and $25^{\circ} \mathrm{C}$ and ideally as fast as possible with moderate agitation to reduce operating costs. Since the powder material does not fully express its functional properties if it remains insoluble, a true solution and/or complete dispersion of colloidal particles is required $[6,14]$. MPC powders are, however, characterized by a low solubility index. In other words, a substantial fraction of powder material remains undissolved after a reasonable time of reconstitution at room temperature $[7,11$, 19]. Moreover, the solubility index decreases with storage time, especially at high storage temperature (up to $50^{\circ} \mathrm{C}$ ) $[1,20]$.

In order to understand this problem, previous research has characterized the nature of the material that remains undispersed after a certain period of MPC85 reconstitution. It was shown to consist mainly of casein micelles linked together by fibril-like protein structures $[7,16]$. Although their nature was not clearly established, these linkages seem to involve weak non-covalent interactions, possibly hydrophobic, between destabilized micelles. Caseins dissociated from the micelles may play a role in inter-micellar associations [1, 7]. As reviewed recently by Singh [20], the native structure of the micelles would have been destabilized by a loss of colloidal calcium phosphate during ultrafiltration and diafiltration steps [16]. Subsequently, during storage of MPC, closely packed and destabilized casein micelles may be more prone to further inter-micellar associations. A water-impermeable skin of 
fused casein micelles may eventually be formed on the powder particles preventing them from being rehydrated [16]. However, further work is needed to better understand the nature of these protein-protein interactions, the conditions of their formation during MPC manufacture and storage and finally, the mechanisms of their disruption during powder reconstitution.

Despite the evidence of a decrease in powder solubility index during storage, it is still unclear whether storage in the dry state provokes the formation of irreversible insoluble material upon reconstitution or only affects the kinetics of dissolution of MPC powder particles. In the latter case, the water transfer toward the interior of the powder particles as the rate-governing step of the rehydration process remains questionable. To further understand the mechanisms operating during powder reconstitution, we have monitored the dissolution kinetics of MPC85 powder and investigated how it is affected by storage. MPC powder contains various components, not only caseins but also whey proteins, minerals and lactose. In this work, the dissolution kinetics of each of these constituents was investigated and from the collected observations, the rate-controlling step of MPC powder rehydration is identified.

\section{MATERIALS AND METHODS}

\subsection{MPC powder}

MPC85 used in this study was provided by Murray Goulburn Co-operative Co. Ltd. (Brunswick, Victoria, Australia). Its chemical composition was analyzed using the methods described in Section 2.3. It contained mainly milk proteins $(87.6 \% \mathrm{w} / \mathrm{w})$, lactose $(3.8 \% \mathrm{w} / \mathrm{w})$ and minerals (Tab. I). Immediately after manufacture, the powder was transported to the laboratory where it was stored at $4{ }^{\circ} \mathrm{C}$ until used. Before rehydration, the powder was removed from the cold
Table I. MPC85 powder composition. The concentrations are given in percentage on dry basis, except for water content expressed in $\mathrm{g} \cdot 100 \mathrm{~g}^{-1}$ powder.

\begin{tabular}{lc}
\hline Water & $6.3 \pm 0.4$ \\
Total proteins & $87.8 \pm 1.4$ \\
Caseins & $71.6 \pm 1.5$ \\
Whey proteins & $16.2 \pm 1.5$ \\
Lactose & $3.8 \pm 0.2$ \\
$\mathrm{Ca}$ & $2.30 \pm 0.06$ \\
$\mathrm{~K}$ & $0.37 \pm 0.01$ \\
$\mathrm{Mg}$ & $0.13 \pm 0.01$ \\
$\mathrm{Na}$ & $0.09 \pm 0.01$ \\
$\mathrm{P}$ & $1.45 \pm 0.04$ \\
\hline
\end{tabular}

room and stored for 2 days at $24{ }^{\circ} \mathrm{C}$ in plastic desiccators ( $250 \mathrm{~mm}$ diameter) above a saturated potassium acetate solution (23\% relative humidity) to ensure moisture content standardization. Changes in powder rehydration properties occurring during a short period of storage in mild conditions were also investigated in this work. For that purpose, MPC85 powder was stored for up to 2 months in the previous conditions of temperature $\left(24{ }^{\circ} \mathrm{C}\right)$ and relative humidity $(23 \%)$.

\subsection{Rehydration procedure}

Rehydration was carried out at 5\% powder concentration in water. MPC85 powder $(10 \mathrm{~g})$ was added to $190 \mathrm{~g}$ of water in a $250 \mathrm{~mL}$ glass beaker. The suspension was maintained at $24^{\circ} \mathrm{C}$ using a water bath. Stirring was performed at constant speed (200 rpm) using an electric overhead mixer (RW20, IKA, Staufen, Germany) and fourblade propeller stirrer of $50 \mathrm{~mm}$ diameter (R 1342, IKA, Staufen, Germany) [17].

\subsection{Dissolution kinetics of powder constituents}

This analytical procedure was adapted from previous reports $[7,17,18]$. The rehydration procedure was repeated twice for 
different periods of time (i.e. 10, 20, 90 and $480 \mathrm{~min}$ ) under controlled conditions of temperature and agitation rate as described in Section 2.2. At the end of each rehydration period, samples of $50 \mathrm{~mL}$ suspension were transferred into $50 \mathrm{~mL}$ centrifugation tubes and centrifuged at $4400 \times g$ for $5 \mathrm{~min}$ at $24{ }^{\circ} \mathrm{C}$. The supernatant was then filtered (GF/A microfiber filter paper, $1.6 \mu \mathrm{m}$ pore size, Whatman) under vacuum. This particular size of $1.6 \mu \mathrm{m}$ was considered as an appropriate cut-off between undispersed and dispersed powder material since no powder particles were detected under this size [17]. Duplicate aliquots of the filtrate were sampled for the determination of total solids, caseins, whey proteins, lactose, calcium, potassium, magnesium and sodium and phosphorus contents. The same chemical analyses were also undertaken in duplicate samples of the bulk suspension. The concentrations in the filtrate of the supernatant were compared to those in the bulk suspension to give the percentage $(\% \mathrm{w} / \mathrm{w})$ of each component present in soluble or dispersed phase (i.e. $<1.6 \mu \mathrm{m}$ ) at different times during powder rehydration.

The solid content was determined by oven drying at $102{ }^{\circ} \mathrm{C}$ for $24 \mathrm{~h} \mathrm{[9].} \mathrm{Lactose}$ was determined by enzymatic method using a Lactose/D-Galactose kit (R-Biopharm, Darmstadt, Germany). Calcium, potassium, magnesium and sodium and phosphorus contents were measured by Inductively Coupled Plasma (Vista-PRO CCD Simultaneous ICP-OES, VARIAN, Palo Alto, CA, USA) after high temperature $\left(200-250{ }^{\circ} \mathrm{C}\right)$ extraction with concentrated nitric and perchloric acids [15]. The element content was measured for $\mathrm{Ca}$ at $422.7 \mathrm{~nm}, \mathrm{~K}$ at $766.5 \mathrm{~nm}, \quad \mathrm{Mg}$ at $279.6 \mathrm{~nm}, \mathrm{Na}$ at $589.0 \mathrm{~nm}$ and $\mathrm{P}$ at $213.6 \mathrm{~nm}$. The total nitrogen (TN) and the soluble nitrogen at pH 4.6 (non-casein nitrogen, $\mathrm{NCN}$ ) were determined according to IDF [10]. For $\mathrm{NCN}$, milk was acidified to $\mathrm{pH} 4.6$ with $1 \mathrm{~mol} \cdot \mathrm{L}^{-1}$ acetate buffer. NCN samples were filtered through Whatman papers
(Whatman Int. Ltd., Maidstone, UK) No. 42. TN and NCN were determined by combustion (Dumas) method [2] using a CNS-2000 Combustion Analyzer (LECO, St. Joseph, MI, USA). Casein and whey protein contents were calculated as follows: $(\mathrm{TN} \times 6.38-\mathrm{NCN} \times 6.25)$ and $(\mathrm{NCN} \times$ 6.25) [13]. Non-protein nitrogen (NPN) was considered as negligible in MPC85.

\section{RESULTS AND DISCUSSION}

\subsection{Kinetics of powder dissolution: Impact of storage}

The dissolution kinetics of MPC85 powders stored for 0,1 and 2 months at $24{ }^{\circ} \mathrm{C}$ and $23 \%$ relative humidity were compared (Fig. 1). We monitored the percentage of solids present in soluble or dispersed phase (i.e. phase composed of particles smaller than $1.6 \mu \mathrm{m}$ ) after 10, 20,90 and $480 \mathrm{~min}$ reconstitution of $5 \%(\mathrm{w} / \mathrm{w})$ powder in water at $24{ }^{\circ} \mathrm{C}$.

In the case of "fresh" powder, only $67 \%$ $(\mathrm{w} / \mathrm{w})$ of the powder material was soluble or dispersed after $10 \mathrm{~min}$ of rehydration. After $100 \mathrm{~min}$, the soluble phase contained $85 \%$ $(\mathrm{w} / \mathrm{w})$ of the initial powder material and around 95\% (w/w) after $480 \mathrm{~min}$ when the dissolution of MPC85 powder was considered as complete since no further increase of total solids in the soluble phase was observed. This length of time for complete rehydration was of the same order of magnitude as reported previously by Laser Light Scattering $[16,17]$. The kinetics of rehydration followed approximately an exponential decay form (straight-line in log scale). After being stored for 1 month, the powder exhibited a sharp decrease in dissolution rate. After 10 min of rehydration, the soluble or dispersed material represented around $40 \%$ of the total, which was about $30 \%$ less than in the case of the "fresh" MPC85 powder after the same time of rehydration. A further decrease in dissolution rate was observed 


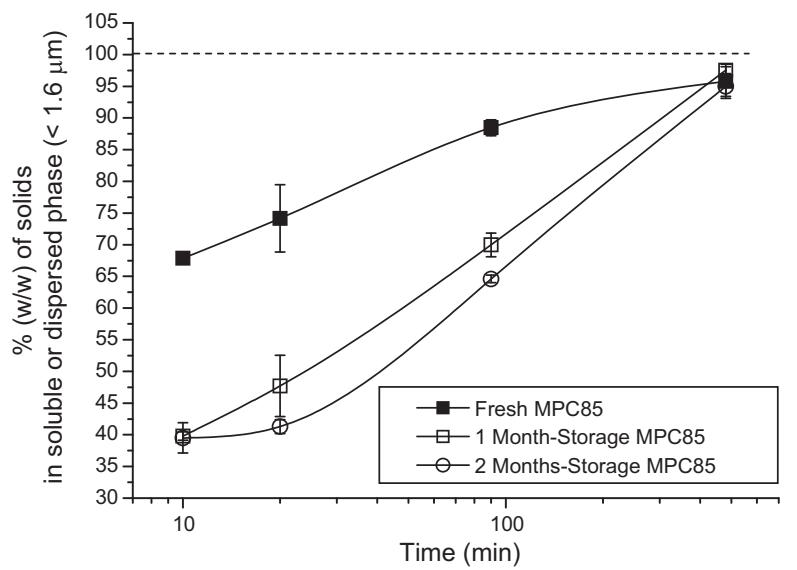

Figure 1. Percentage of powder material present in the soluble or dispersed phase (i.e. particles $<1.6 \mu \mathrm{m}$ ) after different periods of time during powder rehydration. (घ) Fresh milk protein concentrate powder (MPC85); (口) MPC85 powder stored for 1 month at $24{ }^{\circ} \mathrm{C}$ and $23 \%$ relative humidity; and (०) MPC85 powder stored for 2 months in previous conditions.

after the second month of storage, although it was of lower extent. Remarkably, the insoluble fraction (i.e. obtained after the completion of powder dissolution) did not represent more than $5 \%(\mathrm{w} / \mathrm{w})$ of the initial powder material and did not change with storage. These results clearly demonstrate that the storage altered the kinetics of dissolution but did not induce irreversible insolubilization of protein material.

\subsection{Dissolution kinetics of the constituents of MPC85 powder: Impact of storage}

\subsubsection{MPC85 powder composition}

The chemical composition of the MPC85 powder used in this study, as determined with the methods described in Section 2.3, is reported in Table I. This composition was very similar to that measured by the manufacturer using the methods described in Australian Standard 2300 [21] (i.e. $82.4 \%(\mathrm{w} / \mathrm{w})$ of proteins, 3\% $(\mathrm{w} / \mathrm{w})$ of lactose, $7.3 \%(\mathrm{w} / \mathrm{w})$ of minerals and $1.6 \%(\mathrm{w} / \mathrm{w})$ of fat) and also similar to the typical composition of milk protein powder obtained by ultrafiltration [12].

No significant differences in the composition were observed during storage at a probability level of 0.05 (results not shown).

When whey proteins are denatured, they normally precipitate with caseins at $\mathrm{pH}$ 4.6. The whey protein content measured here accounts for native whey proteins. No significant change in this content was observed when MPC85 powder was stored for up to 2 months. Hence, it is likely that whey proteins had not been denatured during this period in accordance with the work of Anema [1] in which whey proteins remained soluble at $\mathrm{pH} 4.6$ and hence were not denatured under adverse conditions of MPC85 storage (i.e. $50^{\circ} \mathrm{C}$ up to 10 days).

\subsubsection{Fast-dissolving constituents}

No significant differences were observed between the lactose content in bulk MPC85 suspension and the concentrations of lactose in the soluble phases separated after 10, 20, 90 and $480 \mathrm{~min}$ of powder rehydration 


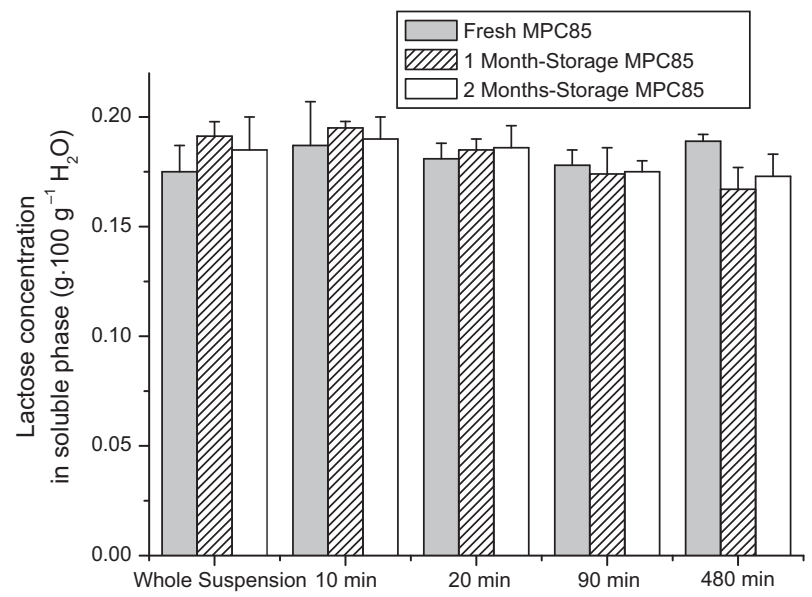

Figure 2. Lactose concentration in 5\% (w/w) MPC85 suspension ("whole suspension") compared with the concentration of lactose present in the soluble or dispersed phase (i.e. particles $<1.6 \mu \mathrm{m}$ ) after different periods of time during powder rehydration. MPC 85 powders stored for 0,1 and 2 months at $24{ }^{\circ} \mathrm{C}$ and $23 \%$ relative humidity are reported. No significant differences were observed at the probability level of 0.05 .

(Fig. 2). These results clearly indicate that after $10 \mathrm{~min}$, all the lactose present initially in the powder was released into the solvent. Moreover, the dissolution kinetics of lactose was not altered after 1 and 2 months of storage of MPC85 powder. Similar results were obtained with whey proteins (Fig. 3) indicating that they were quickly and totally released into the solvent during powder rehydration, even after the powder had been stored for up to 2 months. Their release into the surrounding water was not restrained upon storage, which tends to confirm that the development of the insolubility of MPC powder cannot be attributed to a change in the structure or aggregation state of the whey proteins [1].

These results strongly suggest that water penetration into the powder particles is unlikely to be the rate-limiting factor in the powder rehydration process as molecules larger than water such as lactose and especially whey proteins were freely released out of the powder structure in both fresh and stored powders. This seems to be in accordance with previous work $[3,4]$. Using NMR to monitor the rehydration process of Native Phosphocaseinate (a whey protein-free MPC), Davenel et al. [3, 4] had also shown that it consisted of two steps: an initial and almost instantaneous water absorption by powder (3-5 $\mathrm{g}$ water $\mathrm{g}^{-1}$ powder) in $<2$ min after pouring the powder in water, followed by a second step of slow solubilization of powder particles. For the powder constituents that surround or do not interact with the casein micelles such as native whey proteins or lactose, free access of the solvent to their location would enable their fast solubilization and diffusion into the liquid phase.

Furthermore, considering that the penetration of water into the powder was restrained neither in the case of fresh nor aged MPC, there is no reason to assume that the wetting step played a role in controlling the rehydration rate, confirming previous findings $[6,17]$. If the wetting of the powder had been limiting, the water would not have had access to all the powder material because of the formation of non-hydrated regions. Molecules such as lactose or whey proteins would not have been immediately 


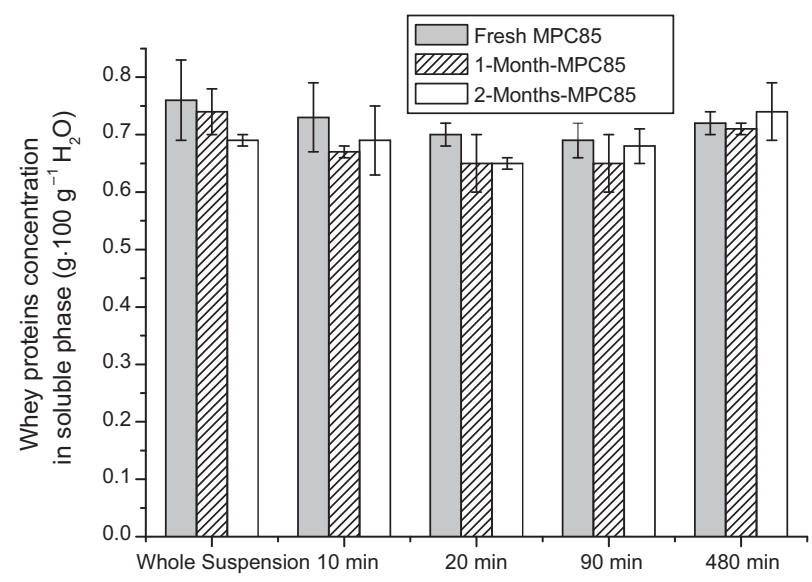

Figure 3. Whey protein concentration in 5\% (w/w) MPC 85 suspension ("whole suspension") compared with the concentration of whey proteins present in the soluble or dispersed phase (i.e. particles $<1.6 \mu \mathrm{m}$ ) after different periods of time during powder rehydration. MPC85 powders stored for 0,1 and 2 months at $24{ }^{\circ} \mathrm{C}$ and $23 \%$ relative humidity are reported. No significant differences were observed at the probability level of 0.05 .

and totally solubilized, as it has been shown in this study (Figs. 2 and 3).

The results reported in Figure 4A showed that, among the mineral species analyzed in this study, sodium and potassium can be considered as almost totally solubilized after $10 \mathrm{~min}$ after starting to rehydrate "fresh" MPC85 powder. Furthermore, after 1 and 2 months of storage at $24{ }^{\circ} \mathrm{C}$ and $23 \%$ relative humidity, no change in sodium and potassium dissolution kinetics was observed (Figs. 4B and 4C). The storage of MPC85 powder did not restrain the diffusion of $\mathrm{Na}$ and $\mathrm{K}$ out of the powder particles.

\subsubsection{Slow-dissolving constituents}

As shown in Figure 4 and in contrast to lactose, whey proteins, $\mathrm{Na}$ and $\mathrm{K}$ (Figs. 2-4), casein, calcium, phosphorus and magnesium were not released instantaneously into the liquid phase. They all follow similar kinetics of dissolution/dispersion. In the case of non-stored powder (Fig. 4A), only $63 \pm 2 \%$ of the caseins present in the powder are found in the dispersed phase after
10 min of rehydration. This percentage increased up to $95 \pm 5 \%$ after $480 \mathrm{~min}$ of rehydration at $24{ }^{\circ} \mathrm{C}$. The kinetics of the release of caseins into the dispersed phase followed approximately an exponential decay form (straight-line in log scale). Calcium, phosphorus and magnesium exhibited approximately the same dissolution kinetics as caseins. Between $55 \%$ and $60 \%$ of the amount present initially in the powder is found in the soluble phase after $10 \mathrm{~min}$, and between $80 \%$ and $90 \%$ after $480 \mathrm{~min}$. Powder storage altered the dissolution kinetics of caseins, calcium, phosphorus and magnesium in the same way. After 1 month of storage, only $35 \%$ of the caseins present in the powder are found in the dispersed phase after $10 \mathrm{~min}$ of rehydration. This percentage decreased to $25 \%$ after 2 months of storage.

\subsection{Rate-limiting step of the rehydration process}

The results reported in Figures 2-4 revealed two types of powder constituents: (i) fast-dissolving species (whey proteins, lactose, potassium and sodium), which 

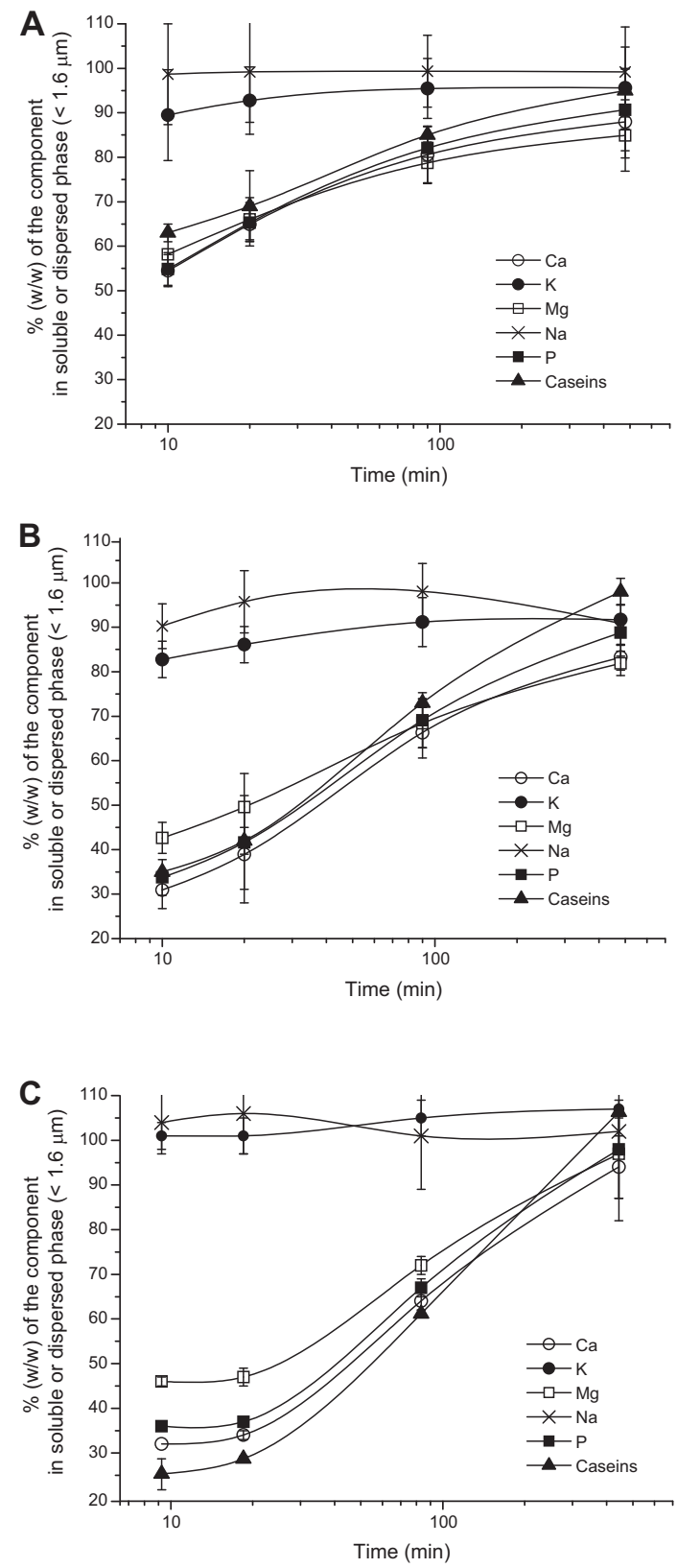

Figure 4. Percentage of $\mathrm{Ca}, \mathrm{K}, \mathrm{Mg}, \mathrm{Na}, \mathrm{P}$ and caseins present in the soluble or dispersed phase (i.e. particles $<1.6 \mu \mathrm{m}$ ) after different periods of time during powder rehydration. (A) Fresh milk protein concentrate powder (MPC85); (B) MPC85 powder stored for 1 month at $24{ }^{\circ} \mathrm{C}$ and $23 \%$ relative humidity; and (C) MPC85 powder stored for 2 months in previous conditions. 
almost instantaneously diffused into the solvent during powder rehydration; their dissolution kinetics were not altered during storage; and (ii) slow-dissolving components (caseins, calcium, phosphorus and magnesium), which all followed the same kinetics of release into the dispersed phase, characterized by a moderately low rate when fresh but further decreased rates after storage. All of the slow-dissolving species belong to the casein micelle structure: about two-thirds of the $\mathrm{Ca}(69 \%)$, one-third of the $\mathrm{Mg}(35 \%)$ and one half of inorganic phosphate $(46 \%)$ and almost all the caseins are colloidal in typical milk [8]. In contrast, the structure of casein micelles does not include any of the fast-dissolving species reported in this study [8]. The step of ultrafiltration during the MPC manufacturing process allows non-micellar components to pass through the membrane along with water, so their concentrations are hardly changed while the concentration of colloidal salts is increased by the volume concentration factor [5]. As a result, nearly all of the $\mathrm{Ca}, \mathrm{Mg}$ and $\mathrm{P}$ present in MPC is colloidal. The fact that all the micellar constituents followed the same kinetics of dispersion with further alteration upon storage strongly suggests that the limiting step of the MPC rehydration process was the release of micelles from the powder particles, which was further restrained following storage. This is in accordance with the nature of the non-dispersed material during reconstitution of MPC that was shown to consist mainly of casein micelles [7, 16]. Moreover, the obstacle to the release of micelles was unlikely to be a limitation of the water transfer to the interior of the powder particles since the non-micellar species diffused freely out of them. This suggests that the micelles may interact with each other forming a relatively loose organization (during the normal storage period), at least porous enough to allow water and nonmicellar constituents to diffuse freely. These attractive interactions or inter-micellar bonds would also be more extensive and/or stronger after extended and/or more severe storage in the dry state, resulting in nonreversible insolubility under standard reconstitution conditions $[1,7]$.

Interactions between micelles did not seem to involve a significant amount of whey proteins as these proteins were not denatured during storage and since they diffused totally and quickly into the solvent regardless of the kinetics of micelle dispersion.

For the same reason, the involvement of lactose in these interactions can be ruled out, although this may be a factor when Maillard reaction becomes prominent after longer periods of storage. Furthermore, weak and reversible bonds more than covalent cross-linking are implicated in the attachment between micelles as gentle agitation and extended reconstitution time were sufficient to allow almost complete dispersion of the micelles (Figs. 1 and 4). It is also possible that only a small fraction of the casein micelles present in MPC are involved in inter-micellar linkages, which, however, may result in the formation of a network. Such a network, if sufficiently extensive, could effectively retard the release of the dominant non-bound casein micelles by simple steric hindrance (i.e. at a scale of tens of nanometers). Finally, considering that dispersion of the micelles was gradual, at least after short-term storage at moderate temperature and low water activity, it seems unlikely to be only restrained by an impermeable layer at the periphery of powder particles that would disrupt after some time and suddenly release non-interacting internal material. It is thus probable that internal interactions between casein micelles also occur.

\section{CONCLUSION}

This study has clarified some aspects of the solubility of MPCs. It confirmed that, for fresh powders or powders stored for a short time under mild conditions, 
the "solubility" determined at a fixed time represents a single point during a slow process that eventually results in nearly complete (ca 95\%) dispersion/dissolution, with storage-induced effects altering the kinetics of dispersion/dissolution but not the final extent. The key finding of the present study is that non-micellar components (whey proteins, lactose, sodium and potassium) are released rapidly, independent of the storage conditions studied, whereas micellar components (caseins, calcium, phosphorus and magnesium) are released slowly with storage slowing the release process further. Taken together, these results suggest that (reversible) association of micelles upon storage is responsible for the reduction in dissolution rate found after short-term storage of MPC.

Acknowledgements: This research was supported by Dairy Innovation Australia Ltd. (DIAL) and the Australian Research CouncilLinkage Project No. LP0669191.

\section{REFERENCES}

[1] Anema S.G., Pinder D.N., Hunter R.J., Hemar Y., Effects of storage temperature on the solubility of milk protein concentrate (MPC85), Food Hydrocoll. 20 (2006) 386-393.

[2] Chiacchierini E., D'Ascenzo F., Restuccia D., Vinci G., Milk soluble whey proteins: fast and precise determination with Dumas method, Anal. Lett. 36 (2003) 2473-2484.

[3] Davenel A., Schuck P., Marchal P., A NMR relaxometry method for determining the reconstitutability and the water-holding capacity of protein-rich milk powders, Milchwissenschaft 52 (1997) 35-39.

[4] Davenel A., Schuck P., Mariette F., Brule G., NMR relaxometry as a non-invasive tool to characterize milk powders, Lait 82 (2002) 465-473.

[5] de la Fuente M.A., Changes in the mineral balance of milk submitted to technological treatments, Trends Food Sci. Technol. 9 (1998) 281-288.

[6] Gaiani C., Schuck P., Scher J., Desobry S., Banon S., Dairy powder rehydration: influence of protein state incorporation mode, and agglomeration, J. Dairy Sci. 90 (2007) 570-581.
[7] Havea P., Protein interactions in milk protein concentrate powders, Int. Dairy J. 16 (2006) 415-422.

[8] Holt C., The milk salts and their interaction with casein, in: Fox P.F. (Ed.), Advanced Dairy Chemistry, Vol. 3: Lactose, Water, Salts and Vitamins, Chapman and Hall, London, UK, 1997, pp. 233-254.

[9] ISO-FIL-IDF, Dried milk and dried cream. Determination of water content, Standard No. 5537, Int. Dairy Fed., Brussels, Belgium, 1993.

[10] ISO-FIL-IDF, Lait. Détermination de la teneur en caséine du lait, Standard No. 17997-1, Int. Dairy Fed., Brussels, Belgium, 2004.

[11] Jimenez Flores R., Kosikowski F.V., Properties of ultrafiltered skim milk retentate powders, J. Dairy Sci. 69 (1986) 329-339.

[12] Jost R., Functional characteristics of dairy proteins, Trends Food Sci. Technol. 4 (1993) 283-288.

[13] Karman A.H., Vanboekel M., Evaluation of the Kjeldahl factor for conversion of the nitrogencontent of milk and milk-products to proteincontent, Neth. Milk Dairy J. 40 (1986) 315-336.

[14] Martin G.J.O., Williams R.P.W., Dunstan D.E., Comparison of casein micelles in raw and reconstituted skim milk, J. Dairy Sci. 90 (2007) 4543-4551.

[15] Martinie G.D., Schilt A.A., Investigation of wet oxidation efficiencies of perchloric-acid mixtures for various organic-substances and identities of residual matter, Anal. Chem. 48 (1976) 70-74.

[16] McKenna A.B., Effect of processing and storage on the reconstitution properties of whole milk and ultrafiltered skim milk powders, Ph.D. Thesis, Massey University, Palmerston North, New Zealand, 2000.

[17] Mimouni A., Deeth H.C., Whittaker A.K., Gidley M.J., Bhandari B.R., Rehydration process of milk protein concentrate powder monitored by static light scattering, Food Hydrocoll. 23 (2009) 1958-1965.

[18] Moughal K.I., Munro P.A., Singh H., Suspension stability and size distribution of particles in reconstituted commercial calcium caseinates, Int. Dairy J. 10 (2000) 683-690.

[19] Schuck P., Piot M., Méjean S., Fauquant J., Brulé G., Maubois J.L., Dehydration of an ultra-clean milk and micellar casein enriched milks, Lait 74 (1994) 47-63.

[20] Singh H., Interactions of milk proteins during the manufacture of milk powders, in: $27 \mathrm{th}$ World Dairy Congress, World Dairy Summit of the Int., Dairy Fed. Proceedings, Shanghai, Peoples Rep. China, 2006, pp. 413-423.

[21] Standards Australia, Methods of chemical and physical testing for the dairying industry, AS 2300.0, Sydney, Australia, 1995. 